

—e ISSN-0976-6847

\title{
Research Article: Study of situational aspects of the farmers in lower Shivalik hills
}

\author{
Priyanka Kandwal and V.K. Rampal
}

Article Chronicle: Received :

19.03.2018;

Revised :

23.06.2018;

Accepted :

06.07.2018
SUMMARY : The study was undertaken with the objective to study the situational aspects of the farmers in lower Shivalik hills. Two hundred and forty respondents from Hoshiarpur district, Punjab and Kangra district, Himachal Pradesh were selected using multistage random sampling design. The data were collected with the help of interview schedule. Findings of the study revealed that majority of respondents had temporary workers in family with employment upto 120 days. Majority had upto 2 migrants in family, with inter-state migration and education as the main reason for migration. Utilization of forest resources by majority of respondents was found to be high in both the district.

How to cite this article : Kandwal, Priyanka and Rampal, V.K. (2018). Study of situational aspects of the farmers in lower Shivalik hills. Agric. Update, 13(3): 321-325; DOI : 10.15740/HAS/AU/13.3/321-325. Copyright@2018: Hind Agri-Horticultural Society.

KEY WoRDS:

Situational,

Employment status, Migration status, Utilization of forest resources 